\title{
Of Ships, and Seals, and Savage Coasts: Samuel Rodman Chace in the Southern Ocean, 1798-1821
}

JOAN DRUETT

Wellington

On 14 May 1798, in the middle of a violent hailstorm, the 80-ton Calcuttabuilt brig Nautilus limped into Sydney Cove, pumping a constant stream of water. ${ }^{1}$ Her captain, an Englishman in the China trade, was Charles Bishop, and amongst his crew was an American he had recruited just four months previously at Hawai'i - a man who was destined to be a major pioneer of sealing grounds in Bass Strait, Tasmania, New Zealand, and the islands of the sub-Antarctic, and an important interpreter of two of the more notorious instances of cultural conflict in early New Zealand. The recruit's name was Samuel Rodman Chace. ${ }^{2}$

Chace, when he joined the crew, did not have the slightest idea that he was fated to play a part in the history of Australasia, or even that he would arrive there; Bishop's plan at the time was to go to the island of Más Afuera for seal skins, and the northwest coast of America for otter furs. The only reason the Nautilus called at Sydney was that she had been blown south by a series of storms. Port Jackson did not promise to be an improvement on what to that time had been a very unlucky voyage, everything being so expensive that Captain Bishop was forced to sell his trade goods to have the ship repaired. ${ }^{3}$ While the shipwrights were at work, however, Bishop struck up a friendship with naval surgeon George Bass, who had recently returned from exploring the south-eastern coast in a whaleboat, and had enlivening tales to tell of beaches where fur seal bulls reigned over large harems. ${ }^{4}$ As a result, on 7 October 1798, when Bass, with Matthew Flinders, left Sydney in the sloop Norfolk to chart the straits that had been bestowed with his name, the Nautilus sailed along too. ${ }^{5}$

Captain Bishop's sights were set on the seals, not geographical discovery. He had every lively expectation, as he wrote to the owners, of harvesting 50,000 skins, 'should we be so fortunate, which with ashurence [sic] we have every reason to expect'. ${ }^{6} \mathrm{He}$ was to be sadly disappointed, mostly because he anchored so far away from the seal nurseries ('rookeries') that his gang wasted time hauling heavy pelts to the ship. When Bishop called back at 
Sydney nearly three months later, on 25 December, chronicler David Collins noted that he had been only 'tolerably successful in seal-catching' and had left ' 14 of his people [including Chace] on the island of Cape Barren, to provide as many skins and as much oil as they could against his return.' ${ }^{7}$ Bishop bargained for provisions, then met up with three local entrepreneurs who wanted to recruit sealers from his gang to overwinter on Cape Barren Island. ${ }^{8}$ When the Nautilus finally left Australia on 27 May 1799, with a disappointing cargo that contributed to a loss-making venture, five of the sealers had opted to stay and work for the colonists, one of them Rodman Chace. ${ }^{9}$

Cape Barren Island was a grim place, composed of granite and thinly clothed with grass and brushwood where venomous snakes abounded, but when Chace arrived back at Port Jackson on 6 March 1800, having been collected by the Sydney syndicate's 31-ton schooner Martha, he reported that it had been pleasant enough. They had experienced very little frost and no severe cold. However, he added, sealing could only be properly pursued in the southern summer months, from November to May. ${ }^{10}$ On 25 July, armed with this experience, he entered into a two-year 'co-partnership' with emancipists Henry Kable and James Underwood:

for the purpose of catching Seals or Sea Lions, tanning such skins, converting or manufacturing the same into upper and sole leather for strong shoes and also for the preserving of the oils of such seals and sea lions for such market as shall be deemed most beneficial for the general interest and advantage of all the parties concerned, except certain prime skins which are specifically to be reserved in their pure state for the China market. ${ }^{11}$

The new consortium's first move was to fit out the 24-ton Underwood-built sloop Diana and put it under the command of Chace, who agreed to use his best endeavours in return for a one-third share of the skins. The Diana sailed to Cape Barren, to remain about twelve months. In November 1802 the partnership was renewed, and out Chace went again, this time accompanied by a veritable fleet of sloops, the local merchants in the meantime having been busily acquiring vessels to meet the ballooning demand.

The sealing boom was by now truly under way, with more than 200 men encamped about Bass Strait. They were provided with clubs, sealing knives, and small boats, along with staves for casks, cauldrons for boiling out oil, and basic provisions. Then they were abandoned for months on end. By any standards, even those of the most miserable convicts back in Sydney, their living conditions were appalling. Huts were built out of stone and sod and thatched with bird wings, but it was not unknown for the men to live in caves, or even under their upturned boats. Clothes, hats, boots, 
and blankets were fashioned from roughly scraped sealskins, which must have smelled as foul as the beaches where the flayed carcasses rotted. The rations provided had to be augmented with seal meat and local game, like kangaroos, wallabies, and birds - mutton birds in particular. But, as long as there were seals to kill and skin, there were men eager to go out and catch them, and sloops and schooners, captained by men like Chace, plied the coast between Sydney and Bass Strait throughout the season. ${ }^{12}$

Because of this, there is a tidal quality to Chace's record at this time, his name appearing in the Sydney Gazette \& New South Wales Advertiser at rhythmic intervals as he coasted in to discharge skins and oil, and left with men, provisions, and tools. He was soon prosperous enough to be a shipowner himself, registering an 11-ton sloop by the name of Good Intent, 'generally employed in Bass Straits. ${ }^{13}$ But, being a shrewd man, he adopted a deliberate strategy of sending the vessel out under another master, while he himself continued to work for Sydney entrepreneurs like John Palmer, Robert Campbell, Henry Kable and James Underwood. This was a political decision, as well as a canny business ploy. Chace was building up relationships that would assure him a place in settler society, an aim that was furthered by his willingness to talk to reporters. Every time he dropped anchor in the cove, it was as if the ripples touched the pages of the paper. All outside news had to come by sea, so the newspaper editors of the information-starved colony welcomed the arrival of even the smallest ocean-going craft. A fellow like Chace, who was willing to share all he had seen and heard, including gossip gleaned from mid-sea visits with other shipmasters, was appreciated beyond price.

It was Chace who broke the news when American competition arrived, despite the fact that the newcomers were his countrymen. On 14 May 1803 the Sydney Gazette reported that three months earlier Captain Chace had fallen in 'with the brig Union, of 120 tons, John Pemberton, Master, from New York, on a sealing expedition'. The captain of this interloper - actually Captain Isaac Pendleton - had anchored in King George's Sound and put a sealing gang on shore at Kangaroo Island, something that the settlement administration was not at all happy to read. Americans were unpopular already, because of the hard-nosed attitude of the Yankee shipmasters who had come in with speculative cargoes that included large amounts of raw New England rum, and who were also notorious for smuggling runaway convicts to sea. ${ }^{14}$ That they should now seek to harvest Australian seals was even more heinous. The sealing trade was designated 'the most considerable among the very few natural productions of this country that can be esteemed commercial', and so it was believed only right that Australian rookeries should be reserved for the benefit of the colony. ${ }^{15}$ 
The strain on the rookeries was immense already, so the rivalry became vicious. In one notorious incident a Yankee crew captured four Cape Barren Island sealers, tied them to trees, and flogged them until their screams brought other colonials to their rescue ${ }^{16}$ The official outrage when the story reached Sydney (plus the fact that the Bass Strait rookeries had in short order been almost wiped out) discouraged American sealers from trying Australian coasts again, but it did not stop them from searching the cold southern seas for new grounds. The Union went on to the Antipodes, a bleak cluster of rocks southeast of New Zealand, and Pendleton left a gang there before visiting Port Jackson, where he entered into a secret, illegal, trading arrangement with Sydney merchant Simeon Lord. Once this was settled, the brig went to Tongatabu for sandalwood, Captain Pendleton being murdered there. The vessel was then wrecked, which left the Antipodes sealers stranded. ${ }^{17}$ However, they worked on regardless. By the time they were rescued, twelve months after being landed, sealing master Owen Folger Smith and his gang had stockpiled the staggering total of 60,000 pelts. ${ }^{18}$

Though great efforts were always made to keep new grounds secret, it was inevitable that news of the bounty further to the south should leak out. Merchant Campbell sent out his 45-ton brig Venus to investigate the rumours, with 29-year-old Scottish adventurer William Stewart in charge, and Rodman Chace as second-in-command. They left Sydney on 29 July 1805, naming their intended destination as 'Bass's Straits', which was doubly deceptive, as the sealing season there would not start until November. ${ }^{19}$ Instead, they steered for Norfolk Island, where they took on supplies, then proceeded to the north of New Zealand on a rather curious mission. Governor King was anxious that the Bay of Islands should be stocked with farm animals that would hopefully become abundant enough to provision future fleets of whaling vessels. Accordingly, the Venus was charged with carrying there two nanny goats and a couple of sows. ${ }^{20}$

The Venus arrived in August, to find the Bay of Islands a very quiet place, at this point a harbour little used by the shipping. There were no Europeans in residence, and so Stewart and Chace dealt directly with Te Pahi, the local chief. Delighted with the animals and other gifts, Te Pahi asked for passage for himself and his four sons to Sydney, in order to thank Governor King in person. Stewart agreed to carry them as far as Norfolk Island. Upon arrival there was a rather embarrassing fuss about fares which, as Te Pahi later bitterly complained to Governor King, the hard-headed Scot tried to force out of the chief by holding one of his sons hostage. ${ }^{21}$ With that difference settled, the Venus set sail for the Antipodes Islands, arriving in November - only to find three American gangs already in possession. Headed by Owen Folger Smith (now working for Lord), the Americans were determined not to share the bonanza. When Stewart responded by hoisting 
the British flag, Folger Smith's men promptly tore it down, tossing it into the sea. In a short bloody confrontation Stewart and his men were forced to retreat to their boats. ${ }^{22}$

The clash must have been a wild scene. Peter Cunningham, a Government surgeon, described a similar skirmish on Macquarie Island several decades later, observing that 'in their long beards, greasy seal-like habiliments, and grim, fiendlike complexions' the sealer-combatants 'looked more like troops of demons from the infernal regions, than baptised Christian men, as they sallied forth with brandished clubs to the contest'. ${ }^{23}$ In this case, further drama was added when a sudden squall drove the Venus out to sea. As Chace tried to beat back to the island the rudder was carried away, this causing so much damage that he decided to return to Port Jackson for repairs, leaving Stewart and his embattled men stranded.

Chace arrived at Port Jackson on 24 January 1806 - but he failed to report that Stewart and his gang were marooned. Instead, he told the Gazette that they had been 'left sealing. ${ }^{24}$ This seemingly unchristian attitude can be explained by the fact that experienced sealers, unlike regular seamen, did not consider being stranded a disaster. Captains frequently sailed away on other business, like freighting or trading, and the gangs were supposed to live on their wits and the land until the mother vessels returned. Also, because of the intrinsic dangers of prowling rockbound coasts in search of rookeries, sealing ships were often wrecked, in which case the gangs were reliant on rescue by the next craft to call. Indeed, Chace had rescued Stewart himself less than three years before, after Stewart's craft George had run ashore at New Year Island. ${ }^{25}$ Nevertheless, when this typically callous attitude is considered, along with the bloodiness and brutality of his trade, Samuel Rodman Chace, despite his cosy relationship with the settlerentrepreneurs and the local press, does not present as a likely member of the cream of Sydney society - which makes it all the more startling that shortly thereafter he married the girl who was arguably one of the most eligible young women in town. ${ }^{26}$

This was fifteen-year-old Marianne Collins, the natural daughter of official David Collins and Ann ('Nancy') Yeats, a Yorkshire milliner who in 1785 had been charged with stealing 36 yards of printed cotton. Transported to New South Wales with the First Fleet on the Lady Penrhyn, Nancy had survived the voyage with a good character, despite being pregnant to one of the seamen, and in due course had become the mistress of David Collins, at that time Judge-Advocate, the third most powerful man in the colony. When she bore him two children - Marianne, on 13 September 1790, and George, in 1793 - Collins made no attempt to keep his proud fatherhood secret. Indeed, he was insensitive enough to combine the names of his mistress - Ann - and his legitimate (and childless) wife back in London - Maria 
- when he christened his daughter. In the same indiscreet spirit, Collins had taken Nancy, Marianne and George with him when he voyaged back to England in 1797. There does not seem to have been any open scandal, but in 1799 Nancy and the children were sent back to Sydney on the Albion. Soon afterwards Nancy married James Grant, a Scottish attorney who had been convicted of forgery, but Collins did not lose touch with his children. After he was appointed Lieutenant-Governor of Van Diemen's Land, Marianne and George lived with him in Hobart. In October 1805 Marianne rejoined her mother in Sydney.

There, on 15 February 1806, in St. Phillip's Church, she married Samuel Rodman Chace. ${ }^{27}$ It is noteworthy that Marianne Collins was just fifteen, though because of the great shortage of respectable marriageable women this was not an unusual age for a bride. It is nevertheless surprising that Chace, who declared himself a widower in the marriage papers and must have been at least twice Marianne's age, should have been considered an acceptable suitor. While possibly a testament to the importance of the skin and oil trade to the early settlement, it is also an illustration of just how well Chace had blended into the local scene. Just one month after the wedding, fellow American Owen Folger Smith came in from the Antipodes and applied to settle in Sydney, but met with an implacable official 'no'. Yet Smith was a major pioneer of sealing at Stewart Island, and had been sponsored by another successful American colonist, Ebor Bunker. Even bribing his way with the first chart of Foveaux Strait (called 'Smith's Strait' for some years) did not help his case. ${ }^{28}$

Even after the honeymoon Chace made no effort to rescue William Stewart, instead sailing to Twofold Bay to salvage the George, which had been wrecked for the second time. Finding it impossible to refloat the hull, he burned it to get at the ironwork. On March 19 he returned to Sydney with 5,000 skins picked up from an unidentifiable gang, and then, on 10 April 1806, he set sail for Van Diemen's Land (Tasmania), having been commissioned by John Palmer to carry commissariat stores to Port Dalrymple. Fatefully, he was also carrying four convicts, two of them young women, who had been assigned to Hobart Town as servants.

The first intimation that something had gone wrong appeared in the 13 July 1806 edition of the Sydney Gazette, under the headline, 'Piratical Capture of the Venus Colonial Brig.' The schooner Governor Hunter had arrived from Port Dalrymple, Van Diemen's Land, 'with Mr Chace late master of the brig Venus and several of his crew' on board, and Chace, as usual, had not been backward in telling the newspaper what had happened. By his account, after leaving Sydney he had taken the Venus to Twofold Bay to collect the ironwork from the George, and had remained there nearly five weeks - a strange decision, considering that he had two young women on 
board. He certainly had cause to be wary. While they were there, he said, he had become worried about the intentions of 'Catherine Hagerty, a convict, who co-habited during the passage with Kelly his first mate.' Indeed, he had asked the captain of the Marcia, then also anchored in Twofold Bay, to report when he got to Sydney that he, Captain Chace, was afraid that 'the vessel was in danger of being run away with.' But instead of returning to Port Jackson himself, he had proceeded to Van Diemen's land.

What Chace did not reveal was that Kelly, a fellow American, had come to the colony as chief officer of the whaleship Albion, and thus was acquainted with Marianne. This was an aspect of the drama that could well have influenced his strange lack of vigilance, even after the two men argued over a cask of spirits that Chace had accused Kelly of broaching. Curiously, Catherine Hagerty had thrown a box of papers belonging to Captain Kemp overboard during the passage from Twofold Bay to Port Dalrymple. Despite these incidents, after the Venus had dropped anchor in the Tamar River Chace was unwise enough to go on board the Governor Hunter for the night. As Governor King remarked later, it was remarkably imprudent behaviour. Even next morning, when he noticed the Venus make sail and get underway, Chace assumed that Kelly was bringing her down the river to save time. A couple of hours later, however, at least according to what he told the Sydney Gazette, he learned the truth:

About 10 o'clock five seamen belonging to the Venus came to the deponent and informed him that they had been forcibly turned out of the vessel . . . and that they further informed the deponent that Kelly, Evans, and Thompson had knocked down and confined the second mate, and had taken the brig out to sea; that Kelly was armed with a musket, Evans with a pistol, and that Thompson was at the helm. ${ }^{29}$

A public notice calling for the arrest of the pirates was posted in Sydney on 18 June 1806, complete with detailed descriptions of the miscreants provided by Chace. ${ }^{30}$ The ring-leader, chief mate Benjamin Barnet Kelly, was 'about 5 feet 7 inches high, pock-marked, thin visage, brown hair, auburn whiskers', while Kelly's inamorata, Catherine Hagerty, was distinguished by 'light hair, fresh complexion, much inclined to smile, and hoarse voice'. The other female convict, Charlotte Badger, was 'very corpulent, with full face, thick lips, and light hair; has an infant child'. The two male convicts were an ex-gunner's mate, Richard Thomas Evans - 'stout made, brown hair, broad visage' - and John William Lancashire, a small, sallow thief with smallpox scars. Richard Thompson, a private in the New South Wales Corps - 'about 27 years of age, fair complexion, and light brown hair' - had been assigned as the convicts' guard, a task at which he had proved remarkably inept. The role of the second mate, Richard Edwards, 
is unclear; it seems that he resisted the insurrection at first but then joined the pirates. He was included in the list of guilty, described as a man 'about 5 feet 5 inches high, fair hair, a very remarkable scar or cut in one cheek'. The public notice concluded:

WHEREAS the persons undermentioned and described did, on the 16th day of June, 1806, by force and arms violently and piratically take away from His Majesty's settlement at Port Dalrymple, a Colonial brig or vessel called the Venus ... This is therefore to caution all Governors, and Officers in Command . . . at whatever Port or Ports the said Brig may be taken into ... to require their being taken into custody wherever found . . . that they may be brought to condign punishment. ${ }^{31}$

However, the pirates of the Venus were by this time well beyond official reach, being on their way to the north of New Zealand. By December they were at the Bay of Islands, where Kelly and Lancashire, with Catherine Hagerty, Charlotte Badger and the child left the ship - and so the first white settlement was established in New Zealand. They were in Te Pahi's territory, and, while the locals treated the Europeans kindly, Kelly and Lancashire were forced to build small huts for themselves, so that the women could live modestly apart. ${ }^{32}$

Command of the Venus then passed to one of the seamen, Joseph Redmonds, whom Chace described as 'a Mulatto, about 5 feet 6 or 7 inches high, stout made, broad nose, thick lips, wears his hair tied, and with holes in his ears, being accustomed to wear large earrings'. From later evidence, it seems that Redmonds had told Kelly that he planned to return to Sydney, but, as he did not know how to navigate, he followed the coast instead, putting in at Bream Head, the Thames and other points on the North Island's eastern coast. Maori women were kidnapped at several of these landfalls. Once the pirates were sexually sated they sold them on to other tribes, who enslaved or killed and consumed them. 'Such are the horrid crimes that Europeans who bear the Christian name commit upon the savage nations!' pronounced Samuel Marsden when he heard of the debauchery. ${ }^{33}$

The female victims included relatives of two prestigious Ngapuhi chiefs, Hongi Hika and Te Morenga, and also Te Haupa, rangatira of the Ngati Maru. This unfortunate coincidence led to the waging of a number of punitive expeditions against the Ngati Porou and the Ngai-te-Rangi, the tribes considered primarily responsible for the deaths and degradation of the highborn women. ${ }^{34}$ Because these raids were staged after several years of barter with whalers and sealers, the scales were tipped against the defenders. The Ngapuhi, who had benefited most from the trade, were well equipped with muskets, while the tribes further south were armed with no more than their traditional spears and clubs. In this cruel introduction to European 
technology, hundreds of uncomprehending warriors were mowed down by shot. 'The conquerors remained three days on the field of battle, feeding upon the slain,' wrote Marsden, 'and then sailed with their prisoners of war. ${ }^{35}$

Naturally, those who lost these grossly uneven battles were anxious to get firearms for themselves, both for defence and to wreak their own savage vengeance. Before the arrival of the pirated Venus, inter-tribal warfare had generally resulted in no more than a handful of fatalities, but thereafter Maori battlefields became a slew of blood. Because of Chace's imprudence, the first sparks of what were to be called 'the musket wars' had been set to the tinder, changing the social landscape of New Zealand for ever. ${ }^{36}$

Back in Port Jackson, public curiosity about the pirates was not satisfied until 9 April 1807, when the colonial brig Commerce made port with news that Kelly and Lancashire had been captured by whaling captains, and that they were on the way to London in shackles. Soon after, the colonial schooner Mercury arrived with a report that the Venus had been seized by a Maori war party at the Coromandel Peninsula. The vessel had been hauled up on a beach and burned for the iron in her hull. Her crew - with the possible exception of Redmonds, who was later reported as being on the Waikato River - had been murdered. ${ }^{37}$ On the same day that the Commerce came into port, the whaler Elizabeth brought the news that Catherine Hagerty had died soon after the convicts had landed at the Bay of Islands, probably of some disease. Charlotte Badger and her child were still living there, she having refused the captain's offer of passage. The fate of the woman popularly known as 'Australia's first female pirate' is a mystery spiced with rumour. Fourteen years after the event, there was talk of a white woman living with a minor chieftain at the Bay of Islands. There is another tale of the captain of the American whaler Lafayette finding a white woman and her half-caste son in the Tonga group. She told him she was Charlotte Badger, and just might have been telling the truth. ${ }^{38}$

Not only had Rodman Chace lost the Venus in humiliating circumstances, William Stewart was still in the Antipodes Islands. As it happened, Stewart had had several chances to leave, ships having arrived to pick up Owen Folger Smith and his sealers, but he had chosen not to take advantage of any of the opportunities. This did not stop him from subsequently taking the owners of the Venus to court. It was not until May 1806 that he accepted the captain of the Star's offer and decided to return. ${ }^{39}$ Arriving back in Sydney on 21 June 1806, he was in town when Rodman Chace returned on the Governor Hunter with the news of the theft of the Venus. What the two men said when they met is not on record, but it may be considered a sign of Governor King's displeasure that when the brig Sophia was sent 
out in pursuit of the pirates it was Stewart, not Chace, who was put in command. ${ }^{40}$

But Chace's luck had not completely deserted him. In late 1806, Captain Abraham Bristow of the London South Seas whaleship Ocean reported the discovery of the Auckland Islands, and Chace was given the command of the 185-ton King George, the largest vessel ever built in the colony, to freight men, tools, and provisions to this new sealing ground. By the start of the 1807 season three gangs had been set ashore. Chace was there again in December 1809 when the Campbell-owned brig Perseverance called. Captain Frederick Hasselburg needed more men, so Chace agreed to let a couple of hands go, and witnessed their signatures. Hasselburg's first mate, Philip Goodenough, wanted to shift to the King George, so he exchanged berths with Miles Holding, Chace's first officer. These exchanges of personnel completed, the two ships parted. Hasselburg headed south, while Chace steered for the Bay of Islands. ${ }^{41}$

Six weeks later Chace was back in Sydney with yet another melodramatic report. 'On Friday arrived the colonial ship King George, Captain Chace, with skins and oil', the story in the Gazette began,

having been at the entrance of the Bay of Islands 18 days previous; Mr. Chace being prevented from entering the Bay from information from the Ann, Captain Gwynn, in company with the Albion, Skelton, from which he received the melancholy information of the [transport ship] Boyd's capture by the New Zealanders under Tippahee, and the massacre of everyone on board except a boy, two women, and a child . . . ${ }^{42}$

A detailed report followed, taken, Chace said, 'from a letter left by Mr. Berry, of the City of Edinburgh, with a friendly chief named Tarrahee, who delivered it to Capt. Gwynn.' According to the letter, John Thompson, captain of the Boyd, 'had contracted with Tippahee for a supply of spars, the delivery of which was protracted for some days by plausible excuses'. Thompson was eventually inveigled into taking two boats, with their crews, 'to a distant part of the island', but no sooner had the boats gone than a native force seized the ship and murdered the passengers and crew on board, all save a half-dozen sailors who fled to the rigging. These men were coaxed down by 'Tippahee', who assured them of their safety, but the instant they complied 'they were immediately bound hand and foot and sent on shore for the purpose of being slaughtered and devoured, which sad destiny unhappily fell upon them after protracted sufferings'. Typically, Chace had more bad tidings, the most notable being the total loss of the whaler Mary, which had run ashore off the East Cape of New Zealand. Fortunately, the crew had been rescued by another ship - the Inspector, he thought. It was his first piece of news, however, that gripped official attention. Two days 
after his revelations became public Chace was ordered to the Magistrates' bench to make a formal deposition. ${ }^{43}$

Interestingly, while he told basically the same story to the Magistrates, Chace avoided naming the leader of the attack, stating instead:

There had been no previous disturbance with the natives, who appeared very friendly, but at the time they rushed on board the Boyd, their war weapons were concealed under their mats, and that after killing all the men on deck they ordered those who had gone aloft to cut the sails from the yards, and that those men were afterwards carried on shore, where, after cutting off their legs and arms, they were roasted.

When he was questioned further he answered evasively, saying that Captain Gwynn had informed him that 'Prince Mattarra' was the principal leader, and that 'Tippahee, when the attack was made on the ship, was in his canoe at some distance'. The reason he was suddenly so careful could have been that 'Tippahee' was none other than Te Pahi, the same chief Chace, with Stewart, had carried to Norfolk Island, and with whom Chace had continued to trade. Furthermore, by stressing that the account had been 'read to him by Capt'n Gwynn from a written paper, and that he, the said Chace, was prevented from taking a copy of it from being anxious to get back to his ship, the night being dark', he successfully distanced himself from any personal knowledge of the facts. Indeed, it is hard to credit that Gwynn went to the trouble of reading the letter aloud to Chace instead of handing it to him to read for himself. It was certainly not because Chace was illiterate, for when he arrived back on board the King George he wrote a letter of his own, warning shipmasters that it could be dangerous to enter the Bay of Islands. He gave this to 'a New Zealander, who had been in the King George for near three years' and who 'could be depended on for delivering it', sending him on shore in a whaleboat, along with some other Maori who had come on board at East Cape.

The letter Captain Gwynn had read to Chace was a copy of one penned on 6 January by Alexander Berry, a merchant of Sydney and supercargo (trading officer) of the City of Edinburgh. After it had been co-signed by the captain and mate, Berry had put it in the care of Captain Swain of the Cumberland, to be sent on to Governor Macquarie. In late April, when he received it, Macquarie forwarded it to the Colonial Secretary, thus lending it some kind of official authority - which was unfortunate, as Berry was a biased interpreter. The merchant had met Te Pahi at Norfolk Island back in 1806, and had been distinctly unimpressed, stating later that he considered him an 'old rascal' who had been 'undeservedly caressed at Port Jackson'. ${ }^{44}$ Furthermore, Berry had no firsthand knowledge of the massacre - just what he had gleaned from talking to the Whangaroa people and a cautious 
reconnoitre of the wreck of the Boyd. He may have interviewed the survivors before he launched himself into writing, but the fact that he mistook the number of women rescued (there was only one, plus a boy and two baby girls) argues that he did not. Even if he had questioned them, their evidence would have been patchy at best, as they were in hiding during the attack. Nor did Berry seem to have had any idea of what might have triggered the atrocity.

A terrible revenge was wreaked before the stories could be checked. On 28 April the Perseverance arrived at Port Jackson with news that the Sydney Gazette published the same day. Captain Hasselburg, at the Bay of Islands with the captains of Speke, Experiment, Diana, Inspector and Atalanta, had 'received intelligence from a young native woman of the destruction of the BOYD, and massacres attending that unfortunate event', with the added information that four Europeans - by the names of Brown, Cook, Anthony, and Harry - were being held hostage. The captains, having assembled a large party of sailors, had been scouring the countryside for the captives when they were confronted by 'a large body of natives' at Te Puna, 'the district of Tippahee', and one seaman had been killed. In the skirmish ' 16 or 18 natives were killed ... [and] Tippahee is stated to have been wounded in the neck and breast'. His son, 'Prince Matyra', the account went on, 'is reported to have been killed by his father in a paroxysm of rage'. The Maori woman informant had been brought to Sydney, 'being no longer safe from the vengeance of the chiefs', and as evidence of 'the horrible treachery practised by Tippahee'. They had heard reliably that he had breakfasted with Captain Thompson of the Boyd 'on the very morning of the massacre'.

Chace, meantime, was back in New Zealand. On 24 March 1810 he was given command of the Governor Bligh, with orders to provision a flaxgathering party at the Bay of Islands and instructions 'to use every endeavour to induce friendly relationships with the natives ${ }^{45}$ He arrived off the coast on 28 April, to be met by a fleet of eight fishing canoes. The New Zealand native who had served on the King George was with them, and he came on board to inform his erstwhile captain that the flax-gatherers had been taken away by the Experiment ten days earlier. Accordingly, Chace decided instead to proceed to Foveaux Strait to relieve some stranded sealers there - who, according to a later statement from their overseer, Robert Murray, would have starved without the fish and potatoes kindly provided by the local Maori - but not before he had gleaned a great deal of news from his contacts in the Bay of Islands. ${ }^{46}$

Much of what Chace had learned was so sensational that, when he arrived back in Sydney on 18 August 1810, he went straight to the Sydney Gazette. The first revelation was that the attack on Te Pahi's village had not been 
at all like the sanitised version delivered by Hasselburg: the captains and sailors 'had manned their boats in the night-time' and attacked Te Pahi's village without warning. Te Pahi was dead, but not as a result of that skirmish. The Ngapuhi chief 'had recently died of a spear wound in his side, received in battle from one of the chiefs of Whangarooa', and the 'king of Whangarooa' had been killed as well. In fact, according to Chace, there were no more chiefs, and the coast was in a state of anarchy. He went on to say that he had gone on shore to confirm this, and had found Te Pahi's village in ruins and his people fired up, Moehanga informing him that the Experiment had only narrowly avoided being attacked:

Mr. Chace used every means in his power to dissuade them from a repetition of the acts that had already drawn vengeance upon them, and held out the very great advantages they would themselves derive from a friendly intercourse with us, which would only be established upon the basis of friendship, and a mutual confidence in each other. . . Mr. Chase [sic], accompanied by a small party, went up to one of their towns ... their constant broils had reduced them to the most wretched state of want . . . their time, which was once usefully employed in cultivation, being now occupied in fortifying themselves against attacks, or in hostile preparations against their neighbours. ${ }^{47}$

'Mr. Chace reaped particulars from a Otaheitan which differs materially from the account already published and which bear the strongest marks of probability', the Gazette article concluded. 'These particulars we necessarily reserve for the next week's publication.'

The second instalment of the story was printed a week later, on 1 September 1810. Once more it began with a description of the eight-canoe fishing fleet, but with the new information that there had been 'a native of Tahiti' with them. 'From him,' the account went on, '[Captain Chace] received details of the massacre of the Boyd which, because he was not one of the New Zealanders, were considered free from their tribal prejudices and rivalries. His version differs considerably from that given by Berry'. Having established the impartiality of his informant, Chace then provided what had so far been lacking - a credible motive for the atrocity. 'When the Boyd went from hence she had on board four or five New Zealanders, who had made part of her crew. These people were displeased at their treatment on the passage, and determined on revenge.' On arrival at Whangaroa - a place that, as Chace carefully pointed out, was 'frequently at war with Tippahee and his subjects' - the dissatisfied Maori seamen consulted with their friends and relatives, 'and the design of taking the ship was formed in consequence'. Promised good spars to top up the Boyd's cargo, Captain Thompson, his chief officer, and three boatloads of men were 'conducted 
to a river, on entering which they were out of sight of the ship'. There the Maori 'threw off the mask and in approbrious [sic] terms upbraided Captain Thompson ... informing him at the same time that he should have no spars there but what he could procure himself'.

The instant Thompson turned away, he and his men were clubbed and axed to death. Dressing up in the dead men's clothes and arriving after dark, the murderers then managed to trick their way onto the ship, killing everyone on deck 'except four or five, who ran up the shrouds, and remained in the rigging the rest of the night'.

The next morning Tippahee appeared alongside in a canoe, and was much offended at what had happened, but was not permitted to interfere or remain near the ship. The unfortunate men in the rigging called him, and implored his protection, of which he assured them if they could make their way to his canoe. This they affected at every hazard, and were by the old chief landed on the nearest point, though closely pursued. The pursuit was continued on shore. They were all overtaken, and Tippahee was forcibly held while the murder of the unhappy fugitives was perpetrated.

Because of Chace's passion for getting information into print, the Sydney public thus learned about Te Pahi's true role in the terrible drama. As in the Venus affair, there were to be repercussions for years to come. The establishment of a mission in New Zealand was delayed for four years, and in the edition for 29 April 1815 the Sydney Gazette commented that the people of the Bay of Islands and Whangaroa had regarded each other "with the most ferocious animosity ever since the destruction of the Boyd . . . on account of the disasters [Te Pahi's tribe] had experienced from that event, though wholly innocent and unconnected with the barbarous transaction.'

Meantime, Rodman Chace had shifted ships yet again, in the course embroiling himself in another conspiracy. In August 1810, when he had dropped anchor in Sydney with the latest intelligence relating to the Boyd affair, it was to find that the 180-ton New York brig Aurora had arrived the previous month, with none other than Owen Folger Smith in command. ${ }^{48}$ Within a few weeks Smith had chartered the Aurora to his old confederate, Simeon Lord, the captaincy being handed over to Chace, but with Smith staying on board to prove American ownership. On 18 September they sailed from Sydney with a crew of 36 sailors and sealers.

The expedition had been triggered by the suspicious behaviour of the Campbell-owned brig Perseverance. ${ }^{49}$ The last Rodman Chace had seen of Captain Hasselburg was in December 1809, when they had separated at the Auckland Islands after exchanging first mates. He had nevertheless had cause to think of him since. Robert Murray, the sealing master rescued from 
Foveaux Strait, was to have been relieved by Captain Hasselburg, who had sailed from Sydney on 25 June after delivering the news of the revengeful attack on Te Pahi's village, but he had never arrived. Instead, to the surprise of all, the Perseverance arrived back in Sydney on 17 August, before the sealing season was even properly underway. There were a number of men missing from the crew, including Chace's erstwhile first officer, Miles Holding, a mystery which Captain Hasselburg tried to pass off by spreading the rumour that he had returned in distress, having lost a boat and six men. The mystery deepened when he bought twelve months' worth of provisions, plus 35 tons of salt for curing skins. The obvious conclusion was that he had discovered a new ground, landed a gang and, in true sealing tradition, was keeping its whereabouts secret. There were attempts to bribe his crew for information about the location of the new ground, but as Hasselburg's sailors had been kept ignorant of the ship's position, all they could tell their inquisitors was that 'the place was dreadfully cold, and the seals were as numerous as flies in a grocer's shop . . . and if they only had plenty of salt, they should have brought in the schooner [sic] as deep as a sand barge, laden with skins. ${ }^{50}$

After recruiting more men, Hasselburg and the Perseverance set sail from Sydney on 7 September 1810, watched closely by Owen Folger Smith and Rodman Chace. Hasselburg was heading for a bleak island-outpost of the sub-Antarctic that he had discovered in early July, on the way to relieve Murray, naming it 'Macquarie' after the current governor of New South Wales. Now the Perseverance was heading back to re-provision the camp set up, and to land a second gang. Ironically, considering that it was the discovery of Macquarie Island that had distracted Hasselburg from relieving him, Robert Murray was on board as first mate and sealing master. They arrived at the new ground at the beginning of October. After landing the extra men, salt and provisions, the Perseverance sailed for yet another island discovered by Hasselburg and kept secret, one first sighted in January 1810, shortly after leaving Rodman Chace and the King George at the Auckland Islands. Hasselburg had named it 'Campbell' after the brig's owner, while he had dubbed the magnificent harbour 'Perseverance' after the brig. $\mathrm{He}$ had set a gang on shore there also, but had been as neglectful of them as he had of Robert Murray. By the time the Perseverance arrived, on 22 October, they were reduced to killing seabirds, their provisions having run out some months before.

The arduous job of taking on board the sealing gang and the cargo of skins they had accumulated was interrupted by two dramatic events. First, Captain Hasselburg was drowned when his boat capsized. Then the brig Aurora arrived, which must have been a shock. It must equally have been a surprise for Chace and Smith to find that Robert Murray was now in 
command of the Perseverance. Owen Folger Smith seems to have seen this as an advantage, Murray owing Chace a favour, having been so recently rescued by him. Chace was sent to offer Murray a bribe. 'I was desired by Captain Smith to get the situation of Macquarie's Island,' Chace later testified:

I saw Murray and asked him for it. He hesitated. I then offered him $£ 150$ and afterwards $£ 200$. He then said he would take a draft for $£ 200$ and give me the situation sealed up. I then went to Captain Smith and got the note. I delivered the note to Murray. The next morning he gave me the above paper sealed up and directed to me. He said it was correct, the true situation of the place and desired me not to open it till we got to sea. ${ }^{51}$

The position given by Murray proved to be misleading. While the latitude was 'pretty correct', the longitude was out by several degrees. 'That description was no help whatever to us in finding out the island for I had instructions from Mr. Lord to cruise nearly in the same latitude'. While they had followed Murray's bearings, this had availed them nothing; they had 'found the land by chance'. Chace and a gang were set ashore on Macquarie, and on 29 December the Aurora arrived back in Sydney. Owen Folger Smith supplied a detailed description of Macquarie Island, complete with location, to the Sydney Gazette. Both Campbell and Macquarie Islands, he said, had been discovered by Captain Hasselburg (now deceased) during the past year: 'there are few seals on either of them, but there is an immense number of sea elephants on Macquarie's Island. ${ }^{52}$

The sea elephant, which is larger than the fur seal and has a long, drooping snout (the origin of its name), was not hunted for its fur, as its hide was only good for leather. However, a thick layer of blubber under that hide could be rendered, like whale blubber, into oil. The population of the beasts on Macquarie was indeed immense. When Chace and his six-man gang arrived back in Sydney on 19 May 1811, having been retrieved by the Aurora, they brought with them 60 tons of oil. Owen Folger Smith now prepared to leave Australia, but before he could do so he was brought to court for non-payment of the bribe to Murray. There had been an attempt to cash the bond on Simeon Lord for the amount of $£ 200$, but on Smith's advice Lord had refused to honour it. Vigorously backed by Rodman Chace, Smith argued that because he had received no value for money the bond was not valid. The court agreed, finding for the defendants.

On 10 July 1811 the Aurora weighed anchor for Calcutta. Rodman Chace took command of the colonial vessel Governor Bligh, and for the next two years freighted men, tools and provisions to Campbell and Macquarie Islands, skins and oil back to Sydney. After his conscientious efforts to 
integrate into the local scene, plus his commitments to his family, staying on in the colony was the obvious decision, but in later years he may well have regretted it. Within a couple of seasons, despite the huge original populations, the numbers of seals and sea elephants had drastically diminished. In just a few years ships that had brought in 100,000 skins were lucky to have $4,500 .{ }^{53}$ Rodman Chace, who had settled in the colony in the expectation of harvesting a fortune, was reduced to finding work where he could.

In September 1814 Chace shipped as mate on the Active, so witnessing the first missionary landing at the Bay of Islands, New Zealand, this being a three-man assessment of the possibilities of setting up a station there. 'At the Derwent Mr. Rodman Chace (an American) entered as mate,' wrote Kendall. ${ }^{54}$ From March 1817 to April 1819 he served as the second officer of the transport Surrey, on voyages to England and the South China Sea. ${ }^{55}$ After that, he moved with Marianne and their six children to Hobart, there taking over command of the colonial vessel Prince Leopold, carrying timber, stores, clothing, dispatches, prisoners and passengers on behalf of the government. In 1823 he took over the Governor Brisbane, having successfully persuaded the authorities that the Prince Leopold was 'a very useless vessel . . good for nothing. ${ }^{56}$

Three years later, in February 1826, Rodman Chace was given his last command, of the brand-new 20-ton colonial schooner Despatch. In March he sailed from Hobart with stores, steering for Maria Island, off the eastern shore of Tasmania, and was never seen or heard from again. After announcing that he had been lost in a gale at sea off Cape Pillar, at the head of Storm Bay, The Colonial Times expressed hope that 'the government may afford some relief to his disconsolate wife and orphan children, as they are left wholly unprovided for, ${ }^{57}$

That Chace should have been reduced to such straitened circumstances was a grim finale, and yet a strangely apposite one. There is a rhythm to the saga of Samuel Rodman Chace that exactly reflects the story of sealing in southern waters. He had connived and speculated, undergone remarkable privation, explored new islands and coasts, played a pivotal part in the colony's first export trade, and yet enjoyed so little profit. At the same time, on beach after beach, island after island, the seals had been destroyed to the very last pup.

1 Charles Bishop, The Journal and Letters of Captain Charles Bishop on the North-West Coast of America, in the Pacific and in New South Wales 1794-1799, (Edited by Michael Roe). Cambridge, Hakluyt Society, Series II, no.131, 1967, pp.294-95; the hailstorm is recorded in the New South Wales Pocket Almanack and Colonial Remembrancer 1806, Facs., Trustees of the Public Library of New South Wales, Sydney, 1966, p.28. Many of the hailstones were ' 6 inches circumf.'. 


\section{Journal of New Zealand Studies}

2 Bishop, Journal and letters, p.265.

3 Bishop, Journal and letters, pp.294-95.

4 Historical Records of New South Wales, (henceforth H.R.N.S.W.), vol.III, p.326.

5 Keith M. Bowden, George Bass, 1771-1803, Melbourne, 1952, pp.78, 85-88.

6 Bishop, Journal and letters, p.290.

7 David Collins, An Account of the English Colony of New South Wales, London, 1798, vol.2, p.137. The gang had harvested only 5,000 skins at the time, and when the Nautilus left Australia she had only 9,000 more.

8 According to J.S. Cumpston, Furneaux Group. Bass Strait, first visitors 1797-1810, Canberra, 1972, p.12, the three entrepreneurs were T.F. Palmer, John Boston, and William Reid, the master of the Francis.

9 R.M. Fowler, The Furneaux Group, Bass Strait - A History, Canberra, Roebuck, 1980, pp.35-37; D. R. Hainsworth, The Sydney Traders: Simeon Lord and his Contemporaries 1788-1821, Melbourne, 1971, pp.128-131; Michael Roe, introduction to The Journal and Letters of Captain Charles Bishop, pp.xli-xlii; Samuel Rodman Chace, American, was known by his second name, Rodman, to avoid confusion with Samuel Chase (often spelled Chace), the English master of the South Seas whalers Harriet and Dubuc, and who was in and out of Sydney from 1805 to 1808, when he was stranded in Australia in 1808 by the wrecking of the Dubuc in the Derwent River. After that, he took over the command of the Pegasus, with William Stewart as his first mate - another cause for confusing the two men. See Basil Howard, Rakiura, A History of Stewart Island New Zealand, Wellington, 1940, pp.339-40.

10 Collins Account of the English Colony, vol.2, pp.153, 288; the Martha had collected 1,300 skins in December. Cumpston, First Visitors, p.12.

11 Supreme Court papers, Misc. Bundle 30, document 10, Copy of Articles. Cited Margaret Steven, Merchant Campbell, A Study in Colonial Trade, Melbourne, 1965, pp.109-11; see also Hainsworth, Sydney Traders, p.131. Chace was described as a 'former officer of the Nautilus,' which indicates that he was Bishop's sealing master.

12 Charles Bateson, Dire Strait, A History of Bass Strait, Wellington, 1973, pp.17-21.

13 H.R.N.S.W. vol. V, p.311; J.S. Cumpston, Shipping Arrivals \& Departures Sydney, 17881825, Canberra, 1963, p.48; Sydney Gazette, 11 Sept. 1803.

14 James Kirker, Adventures to China, Americans in the Southern Oceans, 1792-1812, New York, 1970, pp.102-08.

15 J.S. Cumpston, Kangaroo Island 1800-1836, Canberra, 1970, pp.26-27; Chace arrived May 14, 1803 with the news. H.R.N.S.W. vol.IV, p.890.

16 H.R.N.S.W. vol. V, pp.519-521.

17 H.R.N.S.W. vol. V, p.514.

18 Thomas Dunbabin, 'Whalers, Sealers, and Buccaneers,' Royal Australian Historical Society Journal, vol.XI, 1925, part 1, pp.8-10; Kirker, Adventures to China, pp.113117.

19 H.R.N.S.W. vol. V, p.746.

20 H.R.N.S.W. vol.V, p.601; J. O'C. Ross, William Stewart: Sealing Captain, Trader and Speculator, Canberra, 1987, pp.38-41.

21 Te Pahi ('Tip-pa-he') observed to King that Stewart's behaviour was emoki (lower class) - probably a fair assessment of his character. H.R.N.S.W. vol.VI, p.3.

22 Ross, William Stewart, p.40. The Yankee gangs, headed by Owen Folger Smith, had a secret agreement with Sydney entrepreneur Simeon Lord, which was very much against the rules.

23 Peter Cunningham, Two Years in New South Wales, David S. Macmillan (ed.), Sydney, 1966, letter XXIII, pp.235-36. First published 1827. Cunningham's observations were 


\section{Samuel Rodman Chace in the Southern Ocean, 1798-1821}

based on gossip heard from sealing masters, as he never actually went to the island himself.

24 Cumpston, Shipping Arrivals, p.57; Sydney Gazette, 24 January 1806.

25 Ross, William Stewart, p.17.

26 Alison Alexander, Governors' Ladies: The Wives and Mistresses of Van Diemen's Land Governors, Hobart, 1987, pp.33-34.

27 John Currey, David Collins, A Colonial Life, Melbourne, 2000, pp.112, 227, 328. The marriage notice was published in the Sydney Gazette, 23 Feb. 1806. A great advantage of the marriage for Chace was that he was able to obtain land through his influential father-in-law, as witness a conveyance of Hobart Town land to Chace from Matthew Power, 30 Sept. 1808, Historical Records of Australia (henceforth H.R.A.), Series III, vol.IV, p.786.

28 Opposition to American sealing in Australian territory is itemized in H.R.N.S.W. vol. V, pp.379-80, 513 (with particular reference to Owen Folger Smith's attempt to emulate Chace and settle in the colony); and 717 in particular; Smith's chart is discussed in Ross, William Stewart, p.45-48.

29 Sydney Gazette, 13 July 1806.

30 H.R.N.S.W. vol. VI, pp.98-99.

31 Sydney Gazette, 30 July 1806

32 Robert McNab, From Tasman to Marsden, Dunedin, 1914, pp.110-12; Robert McNab, Historical Records of New Zealand, Wellington, 1908, vol.I, pp.378-79.

33 Samuel Marsden, Letters and Journals 1765-1838. J. Elder (ed.), Dunedin, 1932, p.108.

34 Jack Lee, I have named it the Bay of Islands, Auckland, 1983, pp.42-43.

35 Marsden, Letters and Journals, pp.266-67.

36 R.D. Crosby, The Musket Wars, a History of Inter-Iwi Conflict 1806-45, Auckland, 1999, pp.45-46, 56-58, 71-73.

37 C.W.N. Ingram, New Zealand Shipwrecks 1795-1797, Wellington, 1977, 5th edn, p.3.

38 Eugene Grayland, Coasts of Treachery, Wellington, 1963, pp.28-34. Unsourced.

39 Ross, William Stewart, p.41.

40 Ross, William Stewart, p.52.

41 J.S. Cumpston, Macquarie Island, Melbourne, 1968, p.3.

42 Sydney Gazette, 10 March 1810.

43 H.R.N.S.W. vol. VII, pp.312-15.

44 Berry's letter to the London owners of the City of Edinburgh, quoted in Tony Simpson, Art \& Massacre, Documentary Racism in The Burning of the Boyd, Wellington, n.d., p.7. This monograph is a detailed discussion of Berry and his motives.

45 Sydney Gazette, 25 August 1810.

46 Basil Howard, Rakiura, A History of Stewart Island, New Zealand, Wellington, 1940, pp.36, 339; Murray is quoted in Rhys Richards, Foveaux Whaling Yarns of Yankee Jack, Dunedin, 1995, p.100.

47 Sydney Gazette, 25 August 1810. Moehanga had visited England, having been taken there by John Savage of the London whaleship Ferret in 1805, and because of this was considered a reliable informant. Also see, Lydia Wevers, Country of Writing, Travel Writing and New Zealand 1809-1900, Auckland, 2002, pp.12-33 for a detailed discussion of the various accounts of the Boyd atrocity and its aftermath.

48 Judith Navas Lund, Whaling Masters and Whaling Voyages Sailing from American Ports: A Compilation of Sources, Massachusetts, 2001, p.298; Cumpston, Arrivals, p.71.

49 I.S. Kerr, Campbell Island, A History, Wellington, 1976, p.18. 


\section{Journal of New Zealand Studies}

50 Thomas M. James, Six Months in South Australia, 1842, p.46. Cited in Cumpston, Macquarie Island, pp.10-11.

51 Case of Patrick Cullen v. Owen Folger Smith, Court of Civil Jurisdiction, Sydney, 2 July 1811, cited in Cumpston, Macquarie Island, pp.14-15. Cullen was evidently owed money by Murray and had been given the bond in payment of the debt.

52 Cumpston, Macquarie Island, pp.13-14.

53 Sydney Gazette, 22 April 1815; G.C. Thomson, Misc. Papers. ATL ms-0439/06.

54 John Rawson Elder, Marsden's Lieutenants, Dunedin, 1934, p.55

55 Cumpston, Macquarie Island, p.40.

56 H.R.A. series III, vol.III, p.355.

57 Colonial Times, 23 June 1826; the Govt. agreed to repair the Chace house at 20 Liverpool Street, Hobart, in compensation for his death on government business, but still had not completed the work two years later (Colonial Secretary's Office, 1/26/451). Marianne Letitia Collins Chace died at her residence at Liverpool Street on 23 July 1860, aged 72. (Obituary is in the Hobart Mercury, 26 July 1860) The names of only five of the children are known: Marianne Letitia, born c.1810; George Reynolds, b. 1812, died 20 July 1865 aged 53; Samuel Rodman jr., b. 1814, died 11 Nov. 1880 aged 66; Elizabeth, died 19 Oct. 1852, age unknown; John Douglas, b. 1820, died 23 July 1860 aged 9. Samuel jr.'s death notice (Mercury 12 Nov. 1880) describes him as the 'only surviving son of the late Samuel Rodman Chace of Newborn, North Carolina, U.S.A.', while the obituary of his second daughter, Elizabeth (Examiner 30 October 1852) describes him much more plausibly as 'Samuel Rodman Chace, Master Mariner, many years of these colonies and formerly of Rhode Is., North America.' Chace biographical file, Tasmanian State Archives. 